\title{
AnNa KaPata
}

ORCID: 0000-0002-8554-6517

\section{Sprzedaż wina w ramach lokalnych systemów żywnościowych na przykładzie prawa włoskiego*}

\section{Wprowadzenie}

Wyjaśniając sformułowanie zawarte w tytule, należy zaznaczyć, że lokalne systemy żywnościowe nie zostały dotąd prawnie zdefiniowane. Na potrzeby tego artkułu przyjmuję jako główne kryterium ich wyodrębnienia bliskość geograficzną między producentem żywności a konsumentem, wytwarzanie produktów rolno-spożywczych bezpośrednio przez producentów rolnych oraz sprzedaż w ramach krótkich łańcuchów dostaw. Według prawodawcy unijnego krótkie łańcuchy dostaw obejmują ograniczoną liczbę podmiotów gospodarczych zaangażowanych we współpracę, przyczyniają się do lokalnego rozwoju gospodarczego oraz cechują je ścisłe związki geograficzne i społeczne między producentami i podmiotami zajmującymi się przetwórstwem a konsumentami ${ }^{1}$.

Wsparcie unijne przeznaczone jest na tworzenie takich krótkich łańcuchów dostaw, w których między rolnikiem a konsumentem występuje nie więcej niż jeden pośrednik ${ }^{2}$. Rynki lokalne powinny być zaś zdefiniowane przez

* Artykuł jest efektem realizacji projektu nr 2016/21/D/HS5/03906 finansowanego przez Narodowe Centrum Nauki.

${ }^{1}$ Art. 1 ust. 2 lit. m rozporządzenia Parlamentu Europejskiego i Rady (UE) nr 1305/2013 z dnia 17 grudnia 2013 r. W sprawie wsparcia rozwoju obszarów wiejskich przez Europejski Fundusz Rolny na rzecz Rozwoju Obszarów Wiejskich (EFRROW) i uchylające rozporządzenie Rady (WE) nr 1698/2005, Dz.Urz. UE L 347 z 20.12.2013 r.

2 Zob. art. 11 ust. 1 rozporządzenia delegowanego Komisji (UE) Nr 807/2014 z dnia 11 marca 2014 r. Uzupełniające rozporządzenie Parlamentu Europejskiego i Rady (UE) nr 1305/2013 w sprawie wsparcia rozwoju obszarów wiejskich przez Europejski Fundusz Rolny na rzecz Roz- 
kraje członkowskie poprzez określenie odległości w kilometrach w promieniu gospodarstwa, z którego pochodzi produkt, gdzie musi odbywać się jego przetwarzanie i sprzedaż konsumentowi końcowemu ${ }^{3}$.

Przedmiotem obrotu w ramach lokalnych systemów żywnościowych jest żywność, przez którą, zgodnie z art. 2 rozporządzenia (WE) nr 178/2002, można rozumieć substancje lub produkty przetworzone, częściowo przetworzone lub nieprzetworzone, przeznaczone do spożycia przez ludzi lub których spożycia przez ludzi można się spodziewać ${ }^{4}$. Wino, w świetle powyższego przepisu, zalicza się do środków spożywczych, a ponadto, zgodnie z art. 38 ust. 3 TFUE, jest produktem rolnym, do którego mają zastosowanie przepisy dotyczące wspólnej polityki rolnej, wymienione bowiem zostało w Załączniku I do TFUE 5 .

Definicja wina została określona w rozporządzeniu $\mathrm{nr} 491 / 2009^{6}$. Zgodnie z jego załącznikiem XIb pkt 1 ,,wino jest produktem otrzymywanym wyłącznie w drodze całkowitej lub częściowej fermentacji alkoholowej świeżych winogron, rozgniatanych lub nie, lub moszczu gronowego". Wino musi zatem pochodzić z fermentacji winogron, i to z określonego gatunku, tj. Vitis Vinifera lub krzyżówki tego gatunku z innymi gatunkami Vitis ${ }^{7}$.

Nazwą tą co do zasady, nie może być opatrzony produkt wytworzony z fermentacji innych owoców, taki produkt bowiem zalicza się do napojów spirytusowych z Załącznika II do rozporządzenia 110/2008, jeżeli ma co najmniej $15 \%$ objętości alkoholu ${ }^{8}$. Jednak prawo UE nie przesądza jednoznacznie o braku możliwości zastosowania nazwy wina dla napojów wytworzonych $\mathrm{z}$ fermentacji innych owoców. W takim wypadku, zgodnie $\mathrm{z}$ art. $113 \mathrm{~d}$ ust. 1

woju Obszarów Wiejskich (EFRROW) i wprowadzające przepisy przejściowe, Dz.Urz. L 227/1 z 31.07.2014 r.

${ }^{3}$ Art. 11 ust. 2 rozporządzenia (UE) nr 807/2014.

${ }^{4}$ Rozporządzenie (WE) nr 178/2002 Parlamentu Europejskiego i Rady z dnia 28 stycznia 2002 r. ustanawiające ogólne zasady i wymagania prawa żywnościowego, powołujące Europejski Urząd ds. Bezpieczeństwa Żywności oraz ustanawiające procedury w zakresie bezpieczeństwa żywności Dz.Urz. UE L 31 z 1.02.2002 r.

${ }^{5}$ Wersja skonsolidowana Traktatu o funkcjonowaniu Unii Europejskiej, Dz.Urz. UE C 326 z 26.10.2012 r.

${ }^{6}$ Rozporządzenie Rady (WE) nr 491/2009 z dnia 25 maja 2009 r. Zmieniające rozporządzenie (WE) nr 1234/2007 ustanawiające wspólną organizację rynków rolnych oraz przepisy szczegółowe dotyczące niektórych produktów rolnych (rozporządzenie o jednolitej wspólnej organizacji rynku), Dz.Urz. UE L 154 z 17.06.2009 r.

7 Zob. szerzej na temat prawnej regulacji sektora winiarskiego: A. Germanò, E. Rook Basile, N. Lucifero, Manuale di legislazione vitivinicola, Torino 2017.

${ }^{8}$ Zob. definicję napoju spirytusowego według art. 2 rozporządzenia Parlamentu Europejskiego i Rady (WE) nr 110/2008 z dnia 15 stycznia 2008 r. W sprawie definicji, opisu, prezentacji, etykietowania i ochrony oznaczeń geograficznych napojów spirytusowych oraz uchylające rozporządzenie Rady (EWG) nr 1576/89, Dz.Urz. UE L 39 z 13.02.2008 r. 
lit. a rozporządzenia (WE) 491/2009 konieczne jest wskazanie na etykiecie nazwy owoców. Ponadto wino jest napojem alkoholowym, musi zatem zawierać przynajmniej minimalną wartość procentową alkoholu. Zgodnie z Załącznikiem XIb rzeczywista zawartość alkoholu powinna być, z pewnymi wyjątkami, nie mniejsza niż 8,5\% i nie większa niż 15\% objętości. Do tej kwestii odniósł się Trybunał Sprawiedliwości UE w wyroku z 25 lipca 1991 r. C-75/90 w sprawie Guitard9. W jego następstwie USA i UE zawarły porozumienie 10 marca 2006 r., w którym określiły, że zawartość alkoholu w winie nie może być niższa niż $7 \%$ ani wyższa niż $22 \%$ objętości ${ }^{10}$.

Niniejszy artykuł dotyczy sprzedaży wina, czyli produktu spełniającego wskazane przesłanki, prowadzonej w takich formach, które wpisują się w ideę lokalnych systemów żywnościowych. Sprzedaży powinien zatem dokonywać rolnik będący wytwórcą wina bezpośrednio (lub przy udziale najwyżej jednego pośrednika) do konsumenta końcowego, w bliskiej odległości geograficznej między miejscem wytworzenia a miejscem dostawy. Aby ustalić, w jakich formach, spełniających kryteria lokalnych systemów żywnościowych, w świetle prawa włoskiego możliwa jest sprzedaż wina bezpośrednio przez rolnika będącego jego wytwórcą, przeanalizuję regulacje dotyczące wszystkich form krótkich łańcuchów dostaw przewidzianych we włoskim ustawodawstwie.

\section{Sprzedaż bezpośrednia}

Regulacje wspierające sprzedaż wina bezpośrednio przez producenta mają we Włoszech dość długą tradycję. Już T.U. z zakresu przepisów o bezpieczeństwie publicznym ${ }^{11}$, o którym mowa w dekrecie $1848 / 1926^{12}$, umożliwiał rolnikowi sprzedaż detaliczną wina przez niego wyprodukowanego na terenie własnej winnicy, zwalniając z podlegania ograniczeniom dotyczącym konsumpcji napojów alkoholowych i liczby punktów ich sprzedaży.

Kolejna ustawa $\mathrm{nr}$ 327/1934 o handlu obwoźnym ${ }^{13}$ zezwalała rolnikom na sprzedaż obwoźną własnych produktów, w tym wina, np. do domów konsumentów lub na targowiskach. Obecnie obowiązującą regulacją ogólną w zakre-

\footnotetext{
${ }^{9}$ https://eur-lex.europa.eu/legal-content/EN/TXT/?uri=CELEX\%3A61990CJ0075.

${ }^{10}$ Umowa pomiędzy Wspólnotą Europejską i Stanami Zjednoczonymi Ameryki w sprawie handlu winem, Dz.Urz. UE L 87 z 24.03.2006 r.

${ }_{11}$ Testo unico della legge di pubblica sicurezza (t.u.l.p.s.), Regio decreto 18 giugno 1931, n. 773 (Gazzetta Ufficiale z 26.06.1931, Supplemento Ordinario nr 146).

${ }^{12}$ Regio decreto 6 novembre 1926, n. 1848 Approvazione del testo unico delle leggi di pubblica sicurezza (Gazzetta Ufficiale $\mathrm{nr} 257 \mathrm{z}$ 8.11.1926).

${ }^{13}$ Legge 5 febbraio 1934 n. 327 sul commercio ambulante (Gazzetta Ufficiale nr 60 z 12.03.1934).
} 
sie sprzedaży bezpośredniej produktów rolnych i żywnościowych jest art. 4 dekretu 228/2001 ${ }^{14}$. Uprawnia on przedsiębiorców rolnych do sprzedaży swoich produktów bez konieczności uzyskania specjalnego zezwolenia handlowego, stanowiąc, że ,indywidualni i zrzeszeni przedsiębiorcy rolni, wpisani do rejestru przedsiębiorstw, (...) mogą sprzedawać bezpośrednio detalicznie na całym terytorium Republiki produkty pochodzące w przeważającej mierze $\mathrm{z}$ własnego gospodarstwa, przestrzegając obowiązujących zasad higieny i zdrowia".

Wskazane ułatwienia dotyczące sprzedaży bezpośredniej obejmują nie tylko surowce rolne, ale także wszystkie produkty uzyskane w wyniku przetwarzania lub obróbki produktów rolnych, w tym wino. Wytwarzanie wina jest bowiem działalnością rolniczą powiązaną zarówno w świetle art. 2135 włoskiego k.c., jak i przepisów podatkowych, co potwierdza dekret z 11 lipca 2007 r., określający dobra, które mogą być przedmiotem działalności rolniczych powiązanych ${ }^{15}$. Wśród działalności wymienionych w Załączniku, kwalifikowanych jako działalności rolnicze powiązane, jest produkcja win, octów, cydrów i innych napojów fermentowanych ${ }^{16}$.

Artykuł 4 dekretu 228/2010 przewiduje cztery możliwości prowadzenia sprzedaży bezpośredniej: $\mathrm{w}$ gospodarstwie rolnym lub $\mathrm{w}$ domu, w formie obwoźnej lub w stałym punkcie sprzedaży w miejscach publicznych oraz przez Internet.

W odniesieniu do handlu obwoźnego obowiązuje wymóg powiadomienia gminy, w której znajduje się gospodarstwo rolne, o rozpoczęciu handlu, wraz z podaniem danych wnioskodawcy, wpisu do rejestru przedsiębiorstw, miejsca położenia gospodarstwa, rodzajów produktów będących przedmiotem sprzedaży oraz sposobu ich sprzedaży.

Ułatwienia w zakresie sprzedaży bezpośredniej nie mają zastosowania, jeżeli kwota przychodów ze sprzedaży produktów niepochodzących z gospodarstwa $\mathrm{w}$ poprzednim roku kalendarzowym przekracza 160 tys. euro

${ }^{14}$ Decreto legislativo 18 maggio 2001, n. 228 Orientamento e modernizzazione del settore agricolo, a norma dell'articolo 7 della legge 5 marzo 2001, n. 57 (Gazzetta Ufficiale nr 137 z 15.06.2001, Supplemento Ordinario nr 149).

${ }_{15}$ Decreto 11 luglio 2007 r., Individuazione dei beni che possono essere oggetto delle attivita' agricole connesse di cui all'articolo 32 del testo unico delle imposte sui redditi (Gazzetta Ufficiale $\mathrm{nr} 193 \mathrm{z}$ 21.08.2007).

${ }^{16}$ Pozostałe działalności powiązane, wymienione w Załączniku to: produkcja mięs i produktów mięsnych; obróbka i przechowywanie ziemniaków, z wyłączeniem produkcji puree, snacków i frytek; obróbka i przechowywanie owoców i warzyw, produkcja suchych owoców i warzyw; produkcja oliwy z oliwek i siemienia oleistego, łącznie z kukurydzą (olej kukurydziany), obróbka higieniczna mleka i produkcja przetworów mlecznych; obróbka zboża; suszenie ziół leczniczych, obróbka, rafinacja miodów i ich konfekcjonowanie. 
w przypadku przedsiębiorców indywidualnych lub 4 mln euro w przypadku spółek.

We Włoszech spółki rolne, spółki osobowe i spółki z o.o. oraz spółdzielnie, które zajmują się produkcją winą, mają zgodnie z art. 4 dekretu 99/2004 status przedsiębiorców rolnych, jeżeli ich członkowie są przedsiębiorcami rolnymi i dostarczają winogrona pochodzące $\mathrm{z}$ własnych gospodarstw winiarskich ${ }^{17}$. Podmioty te zostały upoważnione do prowadzenia sprzedaży bezpośredniej na tych samych zasadach, co indywidualni przedsiębiorcy rolni.

\section{Le strade del vino}

Ciekawy instrument prawny w promocji produkcji i sprzedaży wina stanowią ,drogi winne” (le strade del vino), uregulowane ustawą 268/199918 i uzupełnione dekretem z 2000 r. $^{19}$ Są to odpowiednio oznaczone i reklamowane trasy, wzdłuż których występują obszary o walorach przyrodniczych i kulturowych, winnice i piwnice gospodarstw winiarskich otwartych dla zwiedzających. Poprzez ten instrument tereny ze szczególną predyspozycją do produkcji wina mogą być reklamowane $\mathrm{w}$ formie oferty turystycznej. Obszary winiarskie, zgodnie z art. 1 ust. 1 ustawy 268/1999, są to miejsca produkcji wina, zwłaszcza wina wysokiej jakości, objętego systemem tradycyjnych włoskich określeń win: Denominazione d'Origine Controllata (DOC), Denominazione d'Origine Controllata e Garantita (DOCG) oraz Indicazione Geograificha di vini da Tavola (IGT) ${ }^{20}$, a także unijnym systemem jakości Chronionej Nazwy Pochodzenia (ChNP), Chronionego Oznaczenia Geograficznego (ChOG) oraz Gwarantowanej Tradycyjnej Specjalności (GTS). Nazwa drogi winnej może

17 Decreto Legislativo 29 marzo 2004, n. 99 „Disposizioni in materia di soggetti e attività, integrità aziendale e semplificazione amministrativa in agricoltura, a norma dell'articolo 1, comma 2, lettere d, f, g, l, ee, della legge 7 marzo 2003, n. 38" (Gazzetta Ufficiale nr 94 z 22.04.2004).

${ }^{18}$ Legge 27 luglio 1999 n. 268 Disciplina delle „strade del vino” (Gazzetta Ufficiale, Serie Generale nr 185 z 9.08.1999).

${ }_{19}$ Decreto Ministeriale 27 luglio 2000 Fissazione degli standard minimi di qualità per i percorsi individuati ai sensi della Legge 27 luglio 1999 n. 268, recante „Disciplina delle strade del vino" (Gazzetta Ufficiale, Serie Generale nr 175 z 28.07.2000).

${ }^{20}$ Są to tradycyjne określenia pochodzenia win określone we włoskim ustawodawstwie w już nieobowiązującej ustawie: legge 10 febbraio 1992, n. 164 „Nuova disciplina delle denominazioni di origine" (Gazzetta Ufficiale nr 47 z 26.12.1992). Od wejścia w życie wspólnotowego rozporządzenia nr 1234/2007 obowiązują unijne oznaczenia: Chroniona Nazwa Pochodzenia i Chronione Oznaczenie Geograficzne, a krajowe oznaczenia win zostały uchylone. Jednak te ostatnie nadal mogą być stosowane na etykietach win jako „oznaczenia tradycyjne” na podstawie art. 112 rozporządzenia (UE) $\mathrm{nr}$ 1308/2013. 
być tożsama $\mathrm{z}$ nazwą obszaru geograficznego lub z nazwą wina produkowanego na określonym obszarze, która jest $\mathrm{z}$ tym obszarem kojarzona ${ }^{21}$.

Regulacja stanowi zatem instrument promocji określonych obszarów wiejskich poprzez wykorzystanie turystyki. Służy wsparciu rozwoju gospodarczego tych terenów w taki sposób, aby zachować ich walory przyrodnicze i kulturowe. Jej adresatami są przedsiębiorcy rolni, którzy w tworzeniu i zarządzaniu drogami winnymi odgrywają istotną rolę, nie tylko jako producenci dobra, które ma być promowane, ale także pełniący funkcje społeczne „strażników” środowiska i lokalnych tradycji produkcyjnych ${ }^{22}$.

Pierwsze drogi winne we Włoszech powstawały z oddolnej inicjatywy lokalnych producentów w celu promocji produktów, będących symbolem włoskiej kultury winiarskiej ${ }^{23}$. Następnie stały się przedmiotem regulacji regionalnych. Na przykład ustawa regionu Lacjum miała na celu określenie atrakcji turystycznych opartych na promocji lokalnych typowych win, oryginalnych produktów rolnych z danego obszaru, dziedzictwa kulturowego i lokalnych tradycji ludowych, dziedzictwa artystycznego, architektonicznego i zabytków ${ }^{24}$.

Obecnie obowiązująca ustawa nr 268/1999 jest krajową regulacją ramową, określającą główne zasady, według których może działać ustawodawca regionalny, wskazując zasady, cele i kryteria tworzenia „dróg”. Dekret ministra ds. polityki rolnej i leśnej z 27 lipca 2000 r. wprowadza minimalne standardy jakości dla „szlaków tworzonych na podstawie ustawy nr 268/1999”. Stanowi, że muszą one przebiegać przez miejsca, w których wytwarzane są produkty wysokiej jakości w rozumieniu ustawy 164/1992, a także produkty objęte unijnym systemem jakości (ChNP, ChOG, GTS) oraz tradycyjne produkty rolno-spożywcze w rozumieniu dekretu 173/1998 ${ }^{25}$. Dekret ministra z 2000 r. wymaga również uczestnictwa w „drodze winnej” co najmniej dwóch przedsiębiorców rolnych wytwarzających produkt wysokiej jakości, przynajmniej jednego przetwórcy produktu rolnego będącego podstawą produktu żywnościowego wyso-

${ }^{21}$ Zob. art. 1 ust. 1 legge 268/1999 oraz art. 1 Decreto del Presidente della Regione 9 agosto 2002, n. 0239 Regolamento per l'attuazione del capo IV della legge regionale 20 novembre 2000, n. 21 ,realizzazione delle strade del vino” (Bollettino Ufficiale Regionale $\mathrm{nr} 37$ z 11.09.2002).

${ }_{22}$ G. Strambi, Le strade del vino, dell'olio e dei saporiil quadro giuridico di riferimento, „Rivista di Diritto Agrario” 2006, nr 2, s. 206.

23 Ibidem, s. 213.

${ }^{24}$ Art. 1 ust. 6 Legge della Regione Lazio 31 gennaio 1983, n. 12 „Istituzione e gestione delle strade dei vini dei Castelli Romani” (Bollettino Ufficiale Regionale $\mathrm{nr} 7 \mathrm{z}$ 10.03.1983).

${ }^{25}$ Decreto legislativo 30 aprile 1998, n. 173 Disposizioni in materia di contenimento dei costi di produzione e per il rafforzamento strutturale delle imprese agricole, a norma dell'articolo 55, commi 14 e 15, della legge 27 dicembre 1997, n. 449 (Gazzetta Ufficiale, Serie Generale nr 129 z 5.06.1998). 
kiej jakości, co najmniej jednego obiektu zorganizowanego w celu oferowania turystom na sprzedaż produktów objętych „drogą winną” albo muzeum poświęconego danemu produktowi lub działalności wytwórczej w rolnictwie.

Drogi muszą przechodzić przez obszary geograficzne, które cechują się walorami naturalnymi, kulturalnymi, przyrodniczymi, wartymi ochrony i wsparcia. Ponadto powinny być odpowiednio oznakowane i rozreklamowane w celu dostarczenia informacji turystom i odróżnienia tych dróg od innych obszarów. Konieczne jest, aby gospodarstwa winiarskie były otwarte dla turystów, co oznacza, że powinny oferować własne produkty bezpośrednio zwiedzającym. Należy umożliwić turystom zwiedzenie gospodarstwa, aby mogli zapoznać się nie tylko z produktami, ale także z metodami produkcji, wykorzystywanym sprzętem, maszynami ${ }^{26}$. Drogi winne są zatem formą realizacji lokalnych systemów żywnościowych i spełniają kryteria bezpośrednich relacji między producentem a konsumentem, bliskości geograficznej między miejscem wytwarzania a sprzedaży oraz uczestnictwa najwyżej jednego pośrednika między rolnikiem a konsumentem.

\section{Sprzedaż wina w ramach agroturystyki}

Sprzedaż wina, podobnie jak posiłków i innych napojów, zgodnie z ustawą 96/2006 o agroturystyce, jest jedną z działalności agroturystycznych, które może prowadzić przedsiębiorca rolny ${ }^{27}$. Przedmiotem sprzedaży powinny być głównie produkty własne lub pochodzące z okolicznych gospodarstw. Wśród nich przepisy ustawy wymieniają produkty alkoholowe i spirytusowe. Szczególną preferencję zaś przyznają produktom typowym i oznaczonym jako ChNP i ChOG, IGT, DOC, DOCG lub wpisanym na krajową listę tradycyjnych produktów rolnospożywczych (art. 2 ust. $3 b$ ustawy 96/2006).

Ustawa zrównuje z działalnością agroturystyczną działalność przyjmowania i goszczenia, prowadzoną przez gospodarstwa winiarskie w ramach „dróg winnych", w tym serwowanie wina, organizowanie aktywności rekreacyjnych, kulturalnych i dydaktycznych, także poza terenem gospodarstwa rolnego.

Przyjmowanie i goszczenie, podobnie jak wszystkie wymienione usługi, mogą oddzielnie stanowić działalność agroturystyczną pod warunkiem, że spełniają kryteria powiązania z działalnością ściśle rolniczą, która powinna przeważać. Ustawa pozostawia zatem szerokie możliwości organizowania

${ }^{26}$ G. Strambi, Le strade del vino..., s. 218.

${ }^{27}$ Legge 20 febbraio 2006, n. 96 Disciplina dell'agriturismo (Gazzetta Ufficiale nr 63 z 16.03.2006). 
agroturystyki w różnych formach, pozwalając $\mathrm{w}$ ten sposób przedsiębiorcy rolnemu na zachowanie swego uprzywilejowanego statusu prawnego ${ }^{28}$.

Omawiane przepisy znajdują uzasadnienie w świetle celów i zasad ustanowionych w art. 1 ustawy, z którego wynika, że agroturystyka powinna być „zjawiskiem ekonomicznym będącym w stanie uruchamiać możliwości produkcyjne gospodarstwa, podkreślającym jego wielofunkcyjność i zdolnym do podnoszenia wartości terytorium" ${ }^{29}$. Wymóg podawania produktów typowych i posiadających oznaczenia ChNP, ChOG, GTS, DOC i DOCG oraz produktów tradycyjnych służy nie tylko ich promocji i nadaniu ofercie gastronomicznej cech regionalnych, ale też dowartościowaniu terytorium ${ }^{30}$. Ustawa expressis verbis podkreśla w art. 1 lit. f, że Republika włoska wspiera rolnictwo także poprzez promocję turystyki wiejskiej, która ma służyć rozwojowi produkcji lokalnych, produkcji wysokiej jakości i związanych z nimi tradycji winiarskich.

Oferta gospodarstwa agroturystycznego serwującego typowe, lokalne produkty z pewnością jest zgodna z oczekiwaniami konsumentów oraz urzeczywistnia ideę lokalnych systemów żywnościowych. Pozwala rolnikowi na sprzedaż swoich produktów bezpośrednio konsumentowi w miejscu ich wytworzenia, co spełnia kryterium bliskości geograficznej między miejscem sprzedaży a wytworzenia oraz kryterium bliskich relacji między producentem a konsumentem.

\section{Sprzedaż w ramach farmers' markets}

Kolejną formą realizacji lokalnych systemów żywnościowych są famers' markets (rynki rolników). Jest to szczególny rodzaj sprzedaży bezpośredniej, wywodzący się z ogólnej regulacji sprzedaży bezpośredniej produktów rolnych, ustanowionej w art. 4 dekretu ustawodawczego 228/2001. „Rynki rolników” definiuje dekret ministerialny z dnia 20 listopada 2007 r. jako „tereny publiczne lub prywatne przeznaczone do prowadzenia bezpośredniej sprzedaży

${ }^{28}$ C.A. Graziani, Definizione dell'attività agrituristica, w: L. Costato, C.A. Graziani, F. Albisinni et al., Commentario alla legge 20 febbraio 2006, n. 96 «Disciplina dell'agriturismo», „Rivista di Diritto Agrario” 2006, nr 4, s. 437; A. Kapała, Status prawny agroturystyki. Studium prawnoporównawcze, Poznań 2017, s. 49 i n.

${ }^{29}$ L. Paoloni, Commento all'art. 4, w: L. Costato, C.A. Graziani, F. Albisinni et al., Commentario alla legge 20 febbraio 2006..., s. 495.

${ }^{30}$ F. Albisinni, Commento all'art. 2, w: L. Costato, C.A. Graziani, F. Albisinni et al., Commentario alla legge 20 febbraio $2006 \ldots$, s. 467. Szerzej na temat agroturystyki i produktów typowych we Włoszech zob. G. Strambi, Agriturismo e valorizzazione dei prodotti agro-alimentari tipici, „Diritto e Giurisprudenza Agraria e dell'Ambiente” 2007, nr 12, s. 746 i n. 
produktów rolnych wyłącznie przez przedsiębiorców rolnych", wykonujących działalność rolniczą w zasięgu terytorialnym farmers ' market ${ }^{31}$.

Gminy określają zasięg terytorialny poszczególnych rynków oraz wydają postanowienia dotyczące organizacji rynku, regulaminu, polityki cenowej, uczestnictwa w zarządzaniu rynkiem organów administracji publicznej, zakresu kontroli i sankcji. Farmers' markets są zarezerwowane tylko dla przedsiębiorców rolnych, sprzedających produkty rolne w stanie nieprzetworzonym lub przetworzonym, pochodzące $\mathrm{z}$ własnego gospodarstwa lub $\mathrm{z}$ gospodarstwa wspólników, będących przedsiębiorcami rolnymi, jeżeli dochód ze sprzedaży produktów niepochodzących z własnego gospodarstwa w roku kalendarzowym nie przekroczył 160 tysięcy euro dla przedsiębiorców indywidualnych i 4 milionów euro dla spółek. Na terenie rynków rolnych mogą być ponadto organizowane wydarzenia kulturalne, edukacyjne i demonstracyjne związane $\mathrm{z}$ tradycyjnymi, ręcznie wytwarzanymi i sprzedawanymi produktami spożywczymi.

Rynki rolników urzeczywistniają lokalne systemy żywnościowe, spełniają bowiem kryterium bezpośrednich relacji między producentem a konsumentem oraz bliskiej odległości między miejscem wytworzenia a miejscem sprzedaży.

\section{Regulacje dotyczące sprzedaży produktów rolnych i żywnościowych wytworzonych "w promieniu 0 km”}

Instrumentem realizacji lokalnych systemów żywnościowych jest także oznaczenie ,produkty rolne w promieniu 0 kilometrów”, służące ich promocji i wyróżnieniu poprzez podkreślenie ich lokalnego pochodzenia, a w szczególności tego, że zostały wytworzone w bliskiej odległości od miejsca sprzedaży. Oznaczenie zostało wprowadzone we wszystkich regionach Włoch przez ustawy regionalne wspierające krótkie łańcuchy żywności oraz sprzedaż produktów rolnych wytwarzanych w odległości nie większej niż w zależności od regionu - 30 do $80 \mathrm{~km}$ od miejsca, w którym odbywa się sprzedaż lub gdzie znajduje się rynek rolników. Obecnie włoski senat pracuje nad krajowym projektem ustawy, uchwalonym 17 października 2018 r. przez izbę deputowanych, dotyczącym zasad promowania produktów rolnych i spożywczych z krótkiego łańcucha dostaw lub ,Z zera kilometrów”32. Ma on na celu wprowadzenie jednolitych reguł dla wszystkich regionów.

${ }^{31}$ Decreto 20 novembre 2007 Attuazione dell'articolo 1, comma 1065, della legge 27 dicembre 2006, n. 296, sui mercati riservati all'esercizio della vendita diretta da parte degli imprenditori agricoli (Gazzetta Ufficiale, Serie Generale nr 301 z 29.12.2007).

$32 \mathrm{http} / / /$ www.senato.it/leg/18/BGT/Schede/Ddliter/50789.htm. 
Projekt ustawy dotyczy produktów rolnych wymienionych w Załączniku I do TFUE oraz środków spożywczych w rozumieniu art. 2 rozporządzenia WE nr 178/2002, a zatem odnosi się również do wina. Produkty mogą korzystać z instrumentu promocji i wyróżniania, jakim jest oznaczenie ,z zera kilometrów" (a kilometro zero), gdy pochodzą z miejsca produkcji lub przetworzenia surowców rolnych położonych w odległości nie większej niż $70 \mathrm{~km}$ od miejsca sprzedaży lub miejsca konsumpcji. Natomiast produkty rolne lub spożywcze kwalifikują się jako pochodzące z krótkich łańcuchów dostaw, jeżeli są sprzedawane bez udziału pośredników handlowych lub z udziałem tylko jednego pośrednika. Spółdzielnie i ich konsorcja oraz grupy producentów nie są uznawane za pośredników.

\section{Podsumowanie}

Można zauważyć, że ustawodawca włoski oferuje wiele możliwości sprzedaży wina w ramach lokalnych systemów żywnościowych. Wprowadza kilka instrumentów wspierających udział producentów w krótkich łańcuchach żywności. Są one skierowane wyraźnie do rolników (przedsiębiorców rolnych) i dotyczą wytwarzanych przez nich wszystkich produktów rolnych nieprzetworzonych i przetworzonych, w rozumieniu TFUE oraz środków spożywczych w rozumieniu art. 2 rozporządzenia nr 178/2002. Żadna z omówionych regulacji nie wyłączyła ze swego zakresu wina czy innych napojów alkoholowych lub spirytusowych ani jakiegokolwiek rodzaju produktu rolnego lub żywnościowego. Co więcej, dla wina został przewidziany specjalny instrument wspierający jego sprzedaż w ramach krótkich łańcuchów, tj. „drogi winne”, a ustawa o agroturystyce zezwala na serwowanie wina wyprodukowanego $\mathrm{w}$ danym gospodarstwi lub pochodzącego z okolicznych gospodarstw, z warunkiem preferencji dla win typowych z oznaczeniem ChNP, ChOG, DOC, DOCG, IGT.

Omówione instrumenty są formą realizacji idei lokalnych systemów żywnościowych. Zawierają bowiem warunki bliskiej odległości między miejscem wytworzenia a miejscem sprzedaży, bezpośredniej lub bliskiej relacji społecznej między producentem a konsumentem oraz braku pośredników lub uczestnictwa najwyżej jednego pośrednika. Warunki te są spełnione w przypadku każdej formy sprzedaży bezpośredniej, agroturystyki, rynków rolnych, dróg winnych i oznaczenia ,produkty z zera kilometrów”. Możliwość udziału jednego pośrednika przewiduje regulacja „dróg winnych” i ustawy regionalne (a także projekt ustawy krajowej) dotyczące sprzedaży w ramach krótkich łańcuchów dostaw oraz ustawa o agroturystyce, zezwalając na serwowanie wina 
oraz sprzedaż posiłków i napojów składających się z produktów pochodzących z okolicznych gospodarstw. Wymienione instrumenty prawne przyczyniają się również do lokalnego rozwoju gospodarczego i promocji obszarów wiejskich zgodnie z intencją ustawodawcy UE wyrażoną w odniesieniu do krótkich łańcuchów dostaw w rozporządzeniu 1305/2013.

\title{
THE SALE OF WINE WITHIN LOCAL FOOD SYSTEMS ON THE EXAMPLE OF ITALIAN LAW
}

\begin{abstract}
Summary
The purpose of the considerations is to determine in what forms under Italian law wine producers-farmers may sell wine directly to consumers it it meets the criteria of local food systems. In this respect, the regulations on direct sales, so-called "wine routes," agro-tourism, and farmers' markets, as well as the "agricultural products from zero kilometres" indications have been analysed.

It has been established that Italian laws allow selling wine in all the forms of the short supply chains analysed in the study. Legal provisions in this respect govern farmers and the agricultural products they produce, both unprocessed and processed, including wine. What is more, there is a special instrument created to support the sale of wine in short supply chains - "wine routes" while the Law on Agritourism explicitly allows the serving of wine produced on a given farm. All these represent a form of implementing the idea of local food systems where the conditions such as close proximity between the place of production and the place of sale, direct or close social relationship between the producer and the consumer, the lack of intermediaries or the participation of only one intermediary, are satisfied.
\end{abstract}

\section{LA VENDITA DEL VINO NELL'AMBITO DEI SISTEMI ALIMENTARI LOCALI SULL'ESEMPIO DELLA LEGGE ITALIANA}

\section{Riassunto}

L'articolo si propone di esaminare in quali forme, secondo i criteri dei sistemi alimentari locali e alla luce della legge italiana, sia possibile far vendere vino direttamente all'agricoltore che ne è il produttore. Al riguardo, sono state analizzate le regolazioni relative alla vendita diretta, le cosiddette "strade del vino", l' agriturismo, i farmers' markets e i "prodotti agricoli a chilometro zero".

L'analisi svolta permette di far notare che il legislatore italiano offre la possibilità di vendere vino attraverso tutti i tipi di filiere corte richiamati, le quali riguardano gli agricoltori e i prodotti agricoli, da essi prodotti, trasformati o meno, di cui anche il vino. Inoltre, è stato previsto uno strumento speciale - le c.d. "strade del vino", che serve a sostenere la vendita del vino all'interno di filiere corte; la legge di disciplina sull'agriturismo consente, in maniera esplicita, di servire il vino prodotto in azienda. Gli strumenti discussi sono una 
forma di attuazione dell'idea dei sistemi alimentari locali in quanto contengono condizioni di stretta vicinanza tra il luogo di produzione e il luogo di vendita, nonché quelle basate sulle relazioni sociali dirette o strette tra il produttore e il consumatore, come anche l'assenza di intermediari o al limite uno solo. 